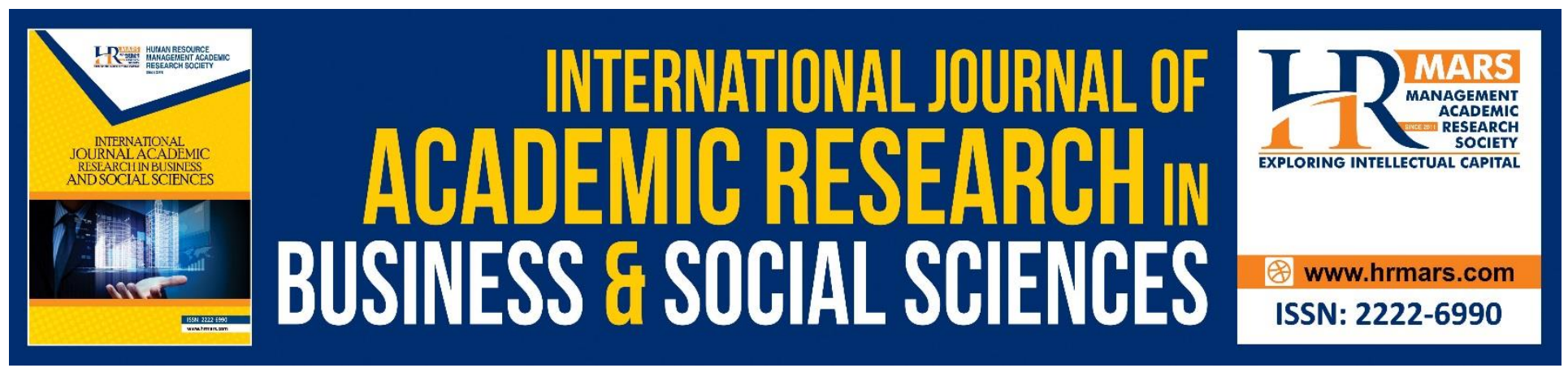

\title{
Job Security, Organizational Support and Employee Performance: Mediating role of Employee Satisfaction in Medical Sector of Pakistan
}

\section{Shama Imam, Tasawar Javed}

To Link this Article: http://dx.doi.org/10.6007/IJARBSS/v9-i3/5793

DOI: 10.6007/IJARBSS/v9-i3/5793

Received: 24 Jan 2019, Revised: 20 Feb 2019, Accepted: 1 March 2019

Published Online: 25 March 2019

In-Text Citation: (Imam \& Javed, 2019)

To Cite this Article: Imam, S., \& Javed, T. (2019). Job security, organizational support and employee performance: mediating role of employee satisfaction in medical sector of Pakistan. International Journal Academic Research Business and Social Sciences, 9(3), 1250-1268.

\section{Copyright: (C) 2019 The Author(s)}

Published by Human Resource Management Academic Research Society (www.hrmars.com)

This article is published under the Creative Commons Attribution (CC BY 4.0) license. Anyone may reproduce, distribute, translate and create derivative works of this article (for both commercial and non-commercial purposes), subject to full attribution to the original publication and authors. The full terms of this license may be seen

at: http://creativecommons.org/licences/by/4.0/legalcode

$$
\text { Vol. 9, No. 3, 2019, Pg. } 1250 \text { - } 1268
$$

Full Terms \& Conditions of access and use can be found at http://hrmars.com/index.php/pages/detail/publication-ethics 


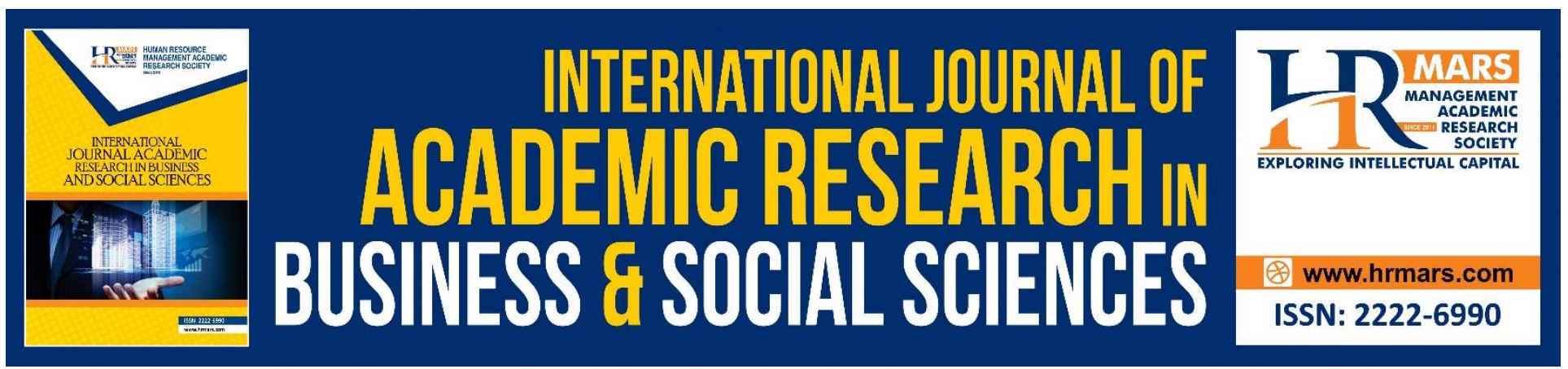

\title{
Job Security, Organizational Support and Employee Performance: Mediating Role of Employee Satisfaction in Medical Sector of Pakistan
}

\author{
Shama Imam \\ Scholar, National College of Business and Economics, Bahawalpur \\ Tasawar Javed \\ Assistant Professor, DMS, IUB
}

\begin{abstract}
The study seeks systemic identification of job security, organizational support and employee satisfaction and investigated impact on employee performance in medical sector of Pakistan .The unit of analysis is an individual medical doctor. Cross sectional survey design has been used for data collection and distribution of instrument as distribution of questionnaire. The random sampling technique is used to conduct the study. The analysis was conducted through SPSS software. The job security and organizational support are independent variables, employee satisfaction is the mediator and employee performance is dependent variable. The study found significant positive relation between job security and employee satisfaction. The study also found positive relation of organization support and satisfaction of employees at medical sectors. If organization supports medical doctors for (their job structure), security and payment policies will be influential towards better performance of employees. The mediating relationship was also found to be significant, study found significant positive relation and mediation effect of employee satisfaction between job
\end{abstract} security, organization support and employee performance.

\section{Introduction \& Background}

Performance is considered as essential element in managing organizations worldwide where outcomes are compared with overall organizational goals and objectives. Organizations have to focus extensively on performance of employees to enhance their capabilities and for achievement of goals. Therefore, performance of doctors in hospitals emerges as an important factor in medical field due to its sensitivity. Due to sensitivity of medical profession as it is physically and psychologically involvement intensive job as it requires long working hours, facing difficult situations, sensitive and heavy process of medical roles. According to (Balch, Freischlag, \& Shanafelt, 2009) stated that doctors 
keep their personal issues and harms distinctively away from professional life in order to update their professional life. Basically, medical doctors play vital role in assisting patients in exchange of responsibilities for increasing life expectations and well-being of society. Therefore, performance of medical doctors needed to be managed and sustain and becomes critical in influencing the health and life expectancy of patients (Royal college of physicians, 2005).

Medical doctors in Pakistan considered as a noble profession due to the nature and sensitivity as it directly influence health and life of people in society. Researchers have stated various performance related issues of medical doctors in Pakistan as insufficient in performing duties caused by frustration which ultimately influence them to quit their job or leave the country for better options. The medical doctors performing their duties in public sector hospitals usually found to be early leaving their premises. This depict irresponsible behavior of doctors which causes various serious issues including neglecting the patients. Khan, Ahmad, Aleem, and Hamed (2011) raised the issues of behavioral problems of doctors at their workplace.

Various factors found to be contributive towards detrimental and negative behavior of medical doctors which includes job insecurity, organizational support (supervisors \& colleagues), nature of job, remuneration and incentives, satisfaction with their job and duties and performance of employees (Okpara, 2004).

The under discussion variables are widely researched in various other business and management fields, but limited literature is available related to medical doctors in Pakistan. Organizational support found to be influential on performance positively, organizational support relates to the health of employees and recognize the efforts of employees at workplace. Organizational justice, support of colleagues \& coworkers, rewards, working conditions, promotions, job security and empowerment found to be as influential antecedents of performance of employees at workplace

According to Kazmi (2011) medical doctors found to be dissatisfied with policies developed, value given to medical doctors, promotional structure, remuneration and other factors which instigate and influence job performance. Medical doctors found to be dissatisfied and disappointed which effect negatively to their performance, the various factors including status, stress, description of their duties and load, personal issues and problems found to be influential on their poor performance (Ghazali, Shah, Zaidi, \& Tahir, 2007).

Various other problems have been reported due to unplanned health services and care which include medical doctors and nurses' ratio, further, Lack of trained doctors, shift of doctors from villages to urban territories and out of country according to Health Issues in Pakistan, (2012) further it was reported in M. Khan (2015). Service structure of medical doctors is poorly defined stated as one of major hurdle and problem in Pakistan as it doesn't offer any attractive rewards in return of performance and technical issues are ignored overtime. In respond to these issues medical doctors involve in detrimental behavior and negative emotions and ignore to join duties in public sector hospitals. They join their duties after marking their attendance and leave premises early, further they remain deviant at workplace in response to emergency. Moreover, the attitude of doctors towards rich and poor patients is different and it negatively impact performance of doctors in public sector hospitals (Health Issues in Pakistan, 2012). 


\section{Problem Statement}

The job security and organizational support influence on the work related outcomes. Organizations have to focus extensively on performance of employees to enhance their capabilities and for achievement of goals (Chen, 2017). Therefore, performance of doctors in hospitals emerges as an important factor in medical field due to its sensitivity. Ghazali et al. (2007) and Khan et al., (2011) reported previously that doctors in all provinces of Pakistan found to be unhappy with their jobs and due to problems in their service structure they have called for strike and stopped working in public sectors hospitals. The policies developed for doctors doesn't reflect their security of job, promotion procedure and remuneration planning which instigated them to initiate strike call and it negatively affect the performance. Further, Khan (2014) also reported negative and problems in associated with doctors' performance and linked it with low salary as $\$ 200 /$ month to provide services in public sector hospitals. The less salary and remuneration packages medical doctors in Pakistan get into dissatisfaction and calls for strikes to compel government to develop better policies, due to these strikes health and life of patients are on risk. Disturbing figures have been reported in relation to increased death rates since 2011 and recently due to strikes almost 500 patients died (Pakistan Health care system, 2018). These strikes were due to promotion policies, remuneration restructuring and job security of medical doctors to satisfy their needs.

Previously, various studies explain multiple reasons of dropped performance such as insecurity of job and studies found positively negative influence of job insecurity on performance (Khan, 2015; Morris, Lydka, \& O'Creevy, 1993). Various other studies conducted research on factors including job insecurity, low salary and remuneration packages, promotion structure issues, absence of autonomy at job, working situations and nature of job significant negatively impact performance of employees. The limited researches are available on the performance of medical doctors of public hospitals in Pakistan and empirical examination is scanty (Khan et al., 2015). Previously various factors have been examined in literature in relation to performance of medical doctors in Pakistan. Hence, current study intends to examine the mediating role of job satisfaction of doctors while considering the relation between job security and support of organization.

Social exchange theory posits that workplace and environmental behavior found to be influential for understanding the phenomenon. The rule of reciprocity claims that perception of employees about their workplace environment, which says if managers are found to be supportive towards employees, secure their employees and appropriate reward; in return employees will be satisfied as reciprocate. It is critically important to investigate performance of doctors' in Pakistani context and related factors. So the current study intend to examine organizational support and reward strategy (financial \& non-financial) towards satisfaction, further which leads towards job performance of medical doctors.

\section{Objectives}

The objectives of the study are threefold. Which includes following:

1) To examine the contribution of organizational support to satisfaction of medical doctors.

2) To examine the influence of job security to satisfaction of medical doctors.

3) To identify the mediating role of satisfaction of doctors and its influence on performance at public sector hospital. 


\section{Literature Review}

Employees perform their duties to meet the goals and objectives of organizations and work related activities compared with allocated tasks are referred as job performance. Researchers and scholars (Bernardin \& Beatty, 1984; Khan, 2015) stated performance of employees can be examined as outcomes and results of performed tasks. Scholar Bright (2007) stated that behaviors of employees at workplace also considered under performance, the behaviors of employees in certain situation and circumstances and their link towards objectives of the organizations. Later, Brunetto and FarrWharton (2002) researchers posited that performance of an employee includes their behavior at workplace and it must be interrelated. Xu, Zhong, and Wang (2013) claims that performance of an employee influenced by various factors which includes leadership of organizations, their style of leadership, knowledge workers, effectiveness of leadership and satisfaction of employees. Further, researchers Berth, Hetty, Hanne \& Filip (2012) stated other factors to be influential which includes job demands, security of their jobs, stress, social support and managing uncertain situations at workplace to examine performance of employees. Organizational support and self-evaluation found to be influential association with performance of employees (Markovits, Davis, Fay, \& Dick, 2010). The direct effects on job performance found to be exerted by various factors including resources allocation, lack of information, committed employees, and role conflict and goal alignment (Jermias \& Yigit, 2012). Shooshtarian, Ameli, and Amini Lari (2013) concluded that motivated employees, their service, pay \& promotion, job safety, freedom at workplace, friendly environment and training positively associated with performance of employees at workplace. Different variables have been examined in past with job performance by various researchers, the results between these variables remained inconclusive as positive or negative overtime. Diverse and inconsistent effects have been examined on performance of employees. There are various comprehensive variables in literature are reported that predict job performance. Moreover, it is recommended by literature to examine other variables according to workplace setting to predict job performance such as the present study has considered as organizational support and job security with satisfaction as mediation effect (Khan, 2015).

\section{Job Security}

Literature has addressed issue of job security in various work settings, as job security is referred as powerlessness of employees at workplace where the environment is threatened (Greenhalgh \& Sutton, 1991). Heaney, Israel, and House (1994) described job security as perception of threat to employee for continues one's job. Job security is also defined as experience of employees to anticipate unwanted and unusual events at workplace relates to loss of job which creates the sense of job insecurity (Sverke \& Hellgren, 2002). It has been reported that medical doctors in Pakistan faced issue related to job insecurity in public sector.

Job insecurity instigates and promotes negative emotions among employees and loses concentration on job task. Unclear and ambiguous situation at workplace causes lack of concentration on work which reduces the performance (Sverke \& Hellgren, 2002). Similarly, medical doctors are unclear about their job and perception of insecurity increases as medical doctors has to renew their contracts after specific time period. 
Various other factors also include scarcity of resources at workplace which causes job insecurity which includes promotion issues, pay and salary packages problems. The organizations with less hierarchal level found to be limited in opportunities of promotion and advancements in service. Insufficient resources in organization attract pejorative activities at workplace which are not appreciated ( Khan, 2015). In context of the present study, medical doctors in Pakistan faces various negative factors which affect their performance and it is reported that one of the major influential factor is fear to loss the job. It has been suggested by literature to investigate effect of job security on performance of employees (Khan, 2015). Following the same line of research, the present study also considers the issue of job insecurity among Pakistani medical doctors to examine their job performance and mediation effect of job satisfaction is examined as satisfaction plays vital role in examining the performance.

\section{Job Security and Job Performance}

Researchers have examined job security and performance empirically and found significant relation (Gabris \& Simo, 1995), similarly, Miller, Erickson, and Yust (2001) found in the study that low job security decreases performance of employees at workplace. Researchers (Khan, 2015; Özyaman, 2007) examined and stated that performance of employees decreases to the increased worrying of employees due to any stress at workplace including job insecurity. Moreover, ( Khan, 2015; Özyaman, 2007; Şenol, 2011) found that if employee perceives job as secure and organization ensure job security; positive outcomes related to performance and commitment gains. The research has been conducted on staff of hotels to examine the job security and behavior of employees, the study reported that job insecurity instigates perception of low job commitment and even further leads to turnover intention, which ultimately effect the performance of employees as well (Khan, 2015).

Job security is identified by researchers as a constant and striking construct for performance and satisfaction. The work environment should not be polluted due to stress or job insecurity perception as it creates detrimental effects on performance, health and well-being of employees. Negative attitude of employees towards job deceases performance and negative outcomes (Cheng \& Chan, 2008; Frone, 2018; Glambek, Skogstad, \& Einarsen, 2018). Negative relation between job security and performance can be expressed according to these possible patterns. 1) Cognitive reasons needs to be focused in order to examine performance and behavior of employees, 2) other external or workplace effects must be considered for examining the effect-based performance.

Psychological theory posits that job security considered as an important factor which is derived through the exchange relation, and may be resulted in loyalty in exchange of ensuring job security and may occur negative outcome in order to exchange with insecurity (Millward \& Brewerton, 2000). De Cuyper and De Witte (2006) stated that employees expect their secure jobs and take it as basic psychological need in order to perform better at workplace, so that is the reason that job security seekers produces equality issue and social exchange relationship among employee and employers, which possible breakout as psychological contract breech among parties (Cuyper \& Witte, 2006; Frone, 2018; Jensen, Opland, \& Ryan, 2010; Khan, 2015). Due to perception of inequality at workplace reduces loyalty and negatively effect on performance of employees according to social exchange relationship (Glambek et al., 2018; Jensen et al., 2010). 
Literature reported inconclusive findings in examining the relationship between job security and performance. Positive relationship has been reported by various scholars (Cheng \& Chan, 2008; Cuyper \& Witte, 2006; Khan, 2015; Millward \& Brewerton, 2000); however, researcher (Ashford, Lee, \& Bobko, 1989; Glambek et al., 2018; Probst, Stewart, Gruys, \& Tierney, 2007; Staufenbiel \& König, 2010) do not find any significant relationship between these constructs.

Therefore, literature has shown inconsistency among relationship of these constructs. It is widely observed that if employees feel secure at workplace they perform better as compare to adverse situation. So, previous research indicated that job performance is affected by sense of security at workplace. Based on previous discussion the present study focused to examine job performance due to job security with mediating effect of satisfaction of employee.

\section{Organizational Support}

Researchers have defined organizational support as value given to employees, contributions of employees and recognition the efforts of employees by organizations. Organizational mind set for valuing the efforts of workers and care about employee well-being (Eisenberger, Fasolo, \& DavisLaMastro, 1990). Various factors joins together to form organizational support which includes working conditions, positive behavior and attitude of employees and human resources management practices. Equal and fair treatment at workplace among employees for rewards and favorable working conditions which are supported by management and strategic apex found to be positive associated with organizational support (Rhoades \& Eisenberger, 2002). On the other hand, efforts of employees at workplace reinforced by organizational support and consequences found to be achievement of goals.

Hence, it is obvious for doctors in public hospital to perform better in return of organizational support. Previous, researchers have identified that medical doctors' performance depends upon organizational support largely.

\section{Organizational Support and Job Performance}

Organizations support their employees in all situations, assisting employee at workplace by employer's projects that responsibility and positive response. It is claimed that organizational support helps employees to perform better in exchange of assistance and recognition given by organization which helps emotionally (Eisenberger et al., 1990). Motivational responsibility generates benefits in exchange as high performance and remarkable efforts in return from employees. Assisting employees at workplace by organizations shows extreme level of interest for organizational support, the assistance doesn't only address to emotional needs, but also helping for equipment, innovative ideas, budgeting, technological adoption and physical support (Hershcovis, Ogunfowora, Reich, \& Christie, 2017; Kraimer, Wayne, Liden, \& Sparrowe, 2005; Li, Liang, \& Farh, 2018; Lin, Chen, Ashford, Lee, \& Qian, 2018).

Scarcity of resources which are contributive towards performance creates hurdle for required outcomes. Lack of resources creates difficulty in achievement of quality product and performance requirement to produce high level of performance by employees. Social exchange theory posits the reciprocity of two way functions, organizational support provided by organizations helps and assist employee to perform well and to gain and achieve objectives of organizations. Organizations provide 
resources of all types required to employees in order to gain positive outcomes for achievement of goals and objectives of the firm for sustainability (Cheung, Wu, \& Chi, 2018; Kraimer et al., 2005; Madden, Kidder, Eddleston, Litzky, \& Kellermanns, 2017).

It is argued that group of employees working in team at workplace exert positive influence over performance and satisfaction of employees. If the satisfaction level of employees increased it further results in better performance of employees, as organizational support helps to gain employee satisfaction and further it helps to gain high level of performance (Hunter, Fears, Jones, \& Rennie, 2018; Sirgy et al., 2006). Researchers have identified various influential factors for performance of employees, such as, remuneration, satisfaction at workplace and with colleagues, promotion opportunities at workplace found to be contributive towards high level of performance and achievement of goals (Kneifel et al., 2012). It is also argued that absenteeism can be controlled by enhancing socialization at workplace among employees and performance can be increased (Fischmann, Witte, Sulea, \& Iliescu, 2018; Posthuma, Campion, \& Campion, 2018; Viswesvaran, 2001). Supervision mechanism found to be supportive in public sector for increase performance, Contrary, organizational support was not found to be influential towards increase or enhance performance of employees at workplace (Sultana, 2009; Talib, Khan, Kiran, \& Ali, 2017; Zafar, 2015).

Above discussion shows the link among these two constructs organizational support and employees' satisfaction and performance. Previous studies found positive and influential relations between these two constructs and few researchers have stated different opinion, as the analysis of both studies have been discussed earlier in the current study in subsequent part. Due to inconclusive results the present study considers to examine the relationship among organizational support and performance of employees at workplace for achievement of objectives and goals of firms.

\section{Job Satisfaction}

Extensive research has been conducted so far as it is one of important factor in workplace setting, but literature has lack of empirical studies on satisfaction of employees at workplace. Literature doesn't project one final definition of job satisfaction, for examining satisfaction level general human nature has to be consider of employees (Aziri, 2011; McGuigan et al., 2018). Various approaches have been taken by researchers, such as job satisfaction is referred as combination of different circumstances which includes physiological, environmental and psychological factors that a person or employee claims to be satisfied with working environment (M. Khan, 2015).

Locke (1976) embarked on defining job satisfaction as "positive and gratifying emotions of employees or individuals towards appraising activities of one's job or experience". Job satisfaction also presents the perception of employees about the resources and things provided by organizations found to be important and significant for examining satisfaction. Further, Luthans (1998) describes three aspects:

$\checkmark$ Satisfaction of employees at workplace described as intangible factor and emotion of an individual while returning from workplace and job activities

$\checkmark$ Achievement of expected outcomes and goals determine satisfaction of employee at job, in explanation it is stated that if an employee perceives that duties assigned to him/her complex or critical or carries extra tasks but in exchange receives less rewards or ignored for efforts, most expectedly gets into negative emotions which leads to poor performance.

$\checkmark$ Related to SET (Social Exchange Theory) it is defined that correlated attitudes found to be 
important factor at job to present satisfaction. As job provides remuneration, promotion, colleagues and management's behavior.

Job satisfaction and Job Performance:

The examination of relation between satisfaction and performance always found to be mixed results, and has controversies among researchers on the relation of these constructs. Researchers have examined the relation of attitudes of employees and their performance, further, research has taken place on the topic of happy workers and high performers and productive. After the study of Hawthore (1930), researchers have found contradictory relations between performance and satisfaction. Moreover, Judge, Thoresen, Bono, and Patton (2001) stated that relation between satisfaction and performance found to be higher when both are appropriate to each other, further the study stated type of jobs and tasks also determine the relationship, as easy task and complex task has different level of satisfaction and performance.

Saari and Judge (2004) posited that attitude of an employee found to be an important factor in explaining satisfaction, which further leads towards higher performance at workplace to gain objectives of an individual and firms. Cole and Cole (2010) published abut satisfaction of employee as pleasurable emotional situation which resulted from job or experience at workplace; and stated it as an attitudinal construct and explained as overall satisfaction. Markovits et al. (2010) stated relation of satisfaction and performance as an evaluation of performed tasks and attitudes of participants in different situations at workplace and on diverse aspects of situation.

The study of Khan (2015) presented relation of satisfaction and performance of employee in school teachers, the findings of study posited that performance of teacher largely affected by satisfaction of teacher at workplace. Whereas; complexity of tasks found to be insignificant between job satisfaction and performance of teachers at workplace.

These mixed results suggested to conduct study for examining mediating role of satisfaction for explaining the phenomenon of job performance of medical doctors in Pakistan influenced by job security and organizational support. The present study entails the constructs including organizational support, job security and their effect on satisfaction which further leads to impact on performance; satisfaction of employees play mediating role among these constructs.

\section{Theoretical context of the Study}

Blau (1964) proposed theory of social exchange which explains the social behavior in exchange of any influencer factor. Current study is underpinned by social exchange theory, whereas supportive management of organization and managers make sure job security of employees and in exchange process optimal performance is gained from the employee at workplace. Job security and organizational support influence the job performance with mediating effect of satisfaction of employees.

\section{Framework}

Current study presents the following framework and variables to be examined. 
INTERNATIONAL JOURNAL OF ACADEMIC RESEARCH IN BUSINESS AND SOCIAL SCIENCES

Vol. 9, No. 3, March, 2019, E-ISSN: 222 2-6990 @ 2019 HRMARS

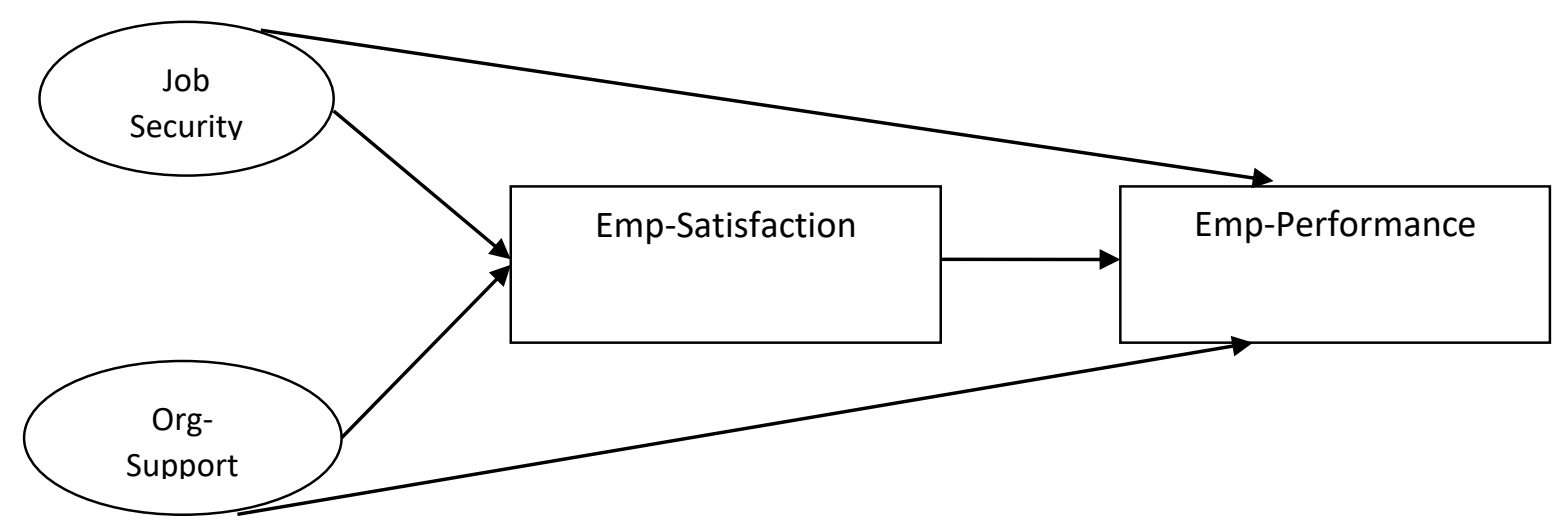

\section{Research Hypothesis:}

$\mathrm{H} 1$ : The significant correlation between job security and performance

$\mathrm{H}$ 2: Organizational support significantly influence performance of employee

H3: Job security significantly influence employee satisfaction

$\mathrm{H}$ 4: Organizational support significantly influence employee satisfaction

H5: Employee satisfaction mediate relationship between job security and performance

H6: Employee Satisfaction mediate relationship between organizational support and performance

\section{Research Design}

Quantitative research approach is applied to examine the relationship presented in framework of the study. The study intend to entails variables named as job security and organizational support as independent variables, and employee satisfaction as mediator, further dependent variable of the study is employee performance and research will be conducted on public sector medical doctors of Pakistan. Thus, unit of analysis of the current study is an individual medical doctor. Cross-sectional survey design has been used for data collection and distribution of instrument, as distribution of questionnaire and collection of data through survey research is commonly and widely used (Bourque \& Fielder, 2003).

\section{Population and Sample of the Study}

The current study conducted on medical doctors of public sector of Pakistan, so the population of the study is considered as all medical doctors of public sector. According to statistics Pakistan Medical and Dental Council (2018) stated that there are total 72,826 medical doctor in Punjab as sample frame for current study. Due to huge population it is not possible to collect data from huge number of medical doctors, so it is suggested to take appropriate sample which truly represent the whole population. Multi stage sampling method is used for the current study for collection of data from medical doctors largely present in province of Punjab, Pakistan. The required sample size is taken as 361 according to the suggestion of Krejcie and Morgan (1970) as appropriate for examined under discussed construct and their relationship. Random sampling technique is used to conduct the study. 


\section{Measurements}

\section{Job Performance}

Rehman (2009) develop the questionnaire to examine the performance of medical doctors consisting on 06 items, measured on seven point Likert Scale, where 1 is considered as strongly disagree, 2 represent disagree, 3 present slightly disagree, 4 as neutral, 5 as slightly agree, 6 as agree and 7 represent higher level of strongly agree.

\section{Job Security}

Kraimer et al. (2005) developed the scale based on 06 items to measure job security among medical doctors. The items measured on the base of 7 point Likert scale as defined previously.

\section{Organizational Support}

Eisenberger (2002) developed scale for measuring organizational support based on 05 items. The measurement took place on based of 7 point Likert scale.

\section{Job Satisfaction}

Rehman (2011) developed 06 item scale for measuring job satisfaction level of medical doctors at workplace. 7 point Likert scale is used as described earlier for measuring the items.

Cronbach Alpha $(\alpha)$ for questionnaire of current study: Table 1 Reliability table of constructs

\begin{tabular}{lllc}
\hline $\mathrm{SR} \#$ & Variables & Items & Alpha $\alpha$ \\
\hline $\mathbf{1}$ & Employee performance & 06 & 0.77 \\
$\mathbf{2}$ & Job security & 06 & 0.90 \\
$\mathbf{3}$ & Organizational support & 05 & 0.90 \\
\hline 4 & Employee satisfaction & 06 & 0.72 \\
\hline
\end{tabular}

\section{Data Analysis}

For comprehensive statistical examination for current study SPSS was chosen as it is considered as most consistent instrument (Buglear, 2005). 
INTERNATIONAL JOURNAL OF ACADEMIC RESEARCH IN BUSINESS AND SOCIAL SCIENCES

Vol. 9, No. 3, March, 2019, E-ISSN: 222 2-6990 @ 2019 HRMARS

Response Rate of Medical Doctors: Table 2

Response Frequency/Rate

Number of distributed questionnaire

400

Total returned questionnaire

345

Useable and completed questionnaires $\quad 275$

$\begin{array}{ll}\text { Response rate } & 69 \%\end{array}$

Descriptive Statistics (Mean and Standard Deviation)

The current study entails the analysis of data while utilizing means and standard deviations. Descriptive statistics reveals that items were measured on 7 point Likert scale, which indicates the diverse response. Table 3 presents that average range of mean values.

Table 4; Mean and SD

\begin{tabular}{lcc}
\hline \multicolumn{1}{c}{ Variables } & Mean & SD \\
\hline Employee Performance & 3.02 & 0.81 \\
Job Security & 3.31 & 0.97 \\
Organizational support & 3.36 & 1.01 \\
Employee Satisfaction & 4.65 & 0.78 \\
\hline
\end{tabular}


INTERNATIONAL JOURNAL OF ACADEMIC RESEARCH IN BUSINESS AND SOCIAL SCIENCES

Vol. 9, No. 3, March, 2019, E-ISSN: 222 2-6990 @ 2019 HRMARS

Inferential Statistics

Correlation Analysis

Table 5: Correlation

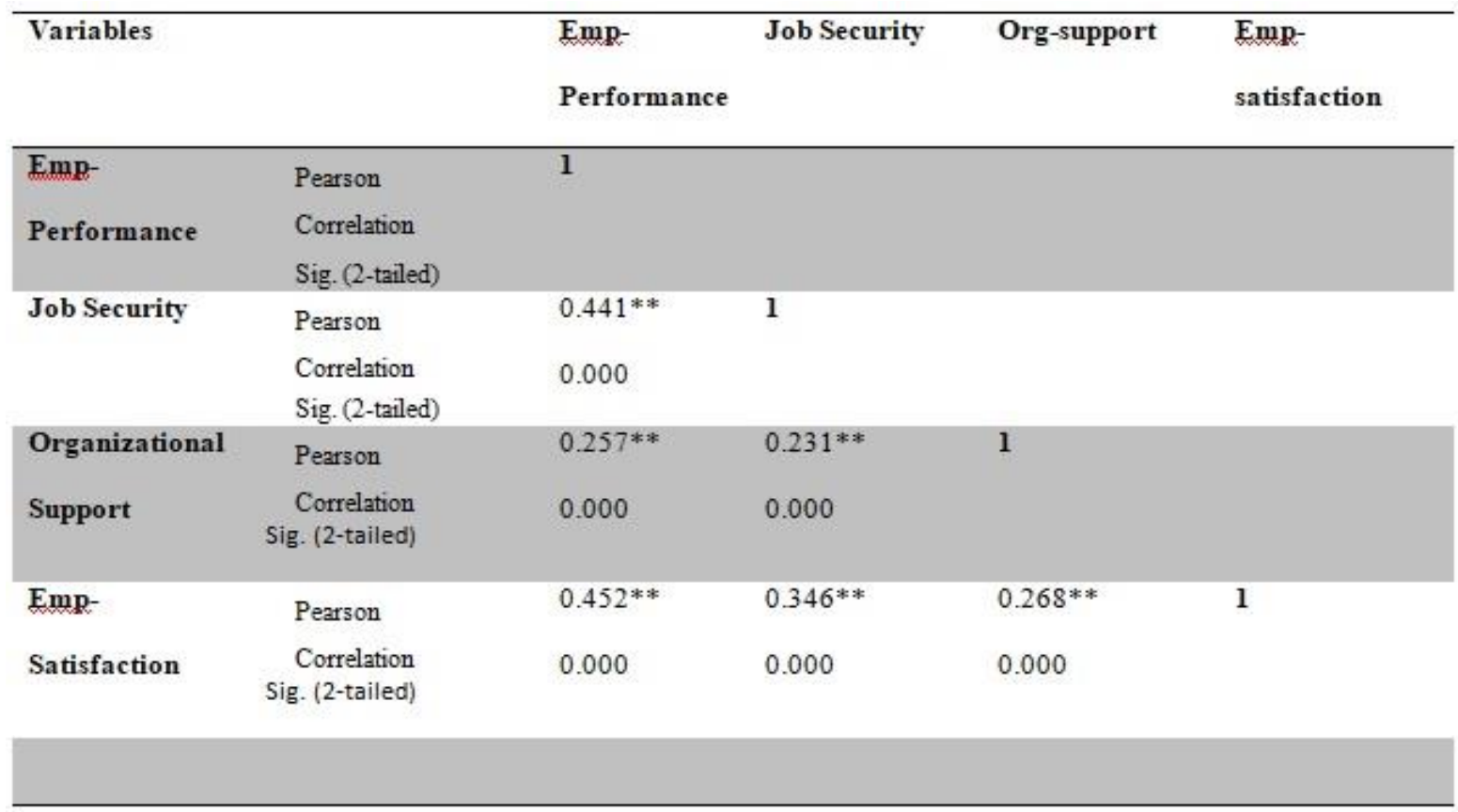

** Significant at level 0.01

\section{Description}

Table 5, shows correlation analysis where significance between variables determine on P Value 0.000 level. Correlation of job performance, job security, org-support and satisfaction found to be significant and values are given in table and all values significant at ' $p$ ' value 0.000 . Job security and performance found to be moderated level as correlation sig level 0.441 and org-support and job performance at lower level of 0.257 . Relation between performance and satisfaction found to be 0.452 as moderate significant.

\section{Hypothesis Testing}

H1: The significant correlation between job security and performance

Above statistics table 5 shows correlation result of the constructs, where correlation was found as 0.441 and $\mathrm{p}<0.01$; which shows positive sig relation among constructs and it shows that $\mathrm{H} 1$ accepted. H2: Organizational support significantly influence performance of employee

Correlation table 5 shows the relation among these two constructs organizational support and job performance; where 0.257 and $\mathrm{p}<0.01$ sig value; which shows $\mathrm{H} 2$ accepted.

H3: Job security significantly influence employee satisfaction

The correlation was analyzed where the two variables were found at 0.346 ; with $p<0.01$; hence it shows that $\mathrm{H} 3$ is supported. 
INTERNATIONAL JOURNAL OF ACADEMIC RESEARCH IN BUSINESS AND SOCIAL SCIENCES

Vol. 9, No. 3, March, 2019, E-ISSN: 222 2-6990 @ 2019 HRMARS

H4: Organizational support significantly influence employee satisfaction

The value of correlation among these variables found to be 0.268 with $p<0.01$; and it shows low positive sig correlation. Hence, $\mathrm{H} 4$ is supported.

\section{Mediating Effects}

H5: Employee satisfaction mediate relationship between job security and job performance

The results in table 6 shows the mediation results of above stated hypothesis. The result shows sig mediating effect of job satisfaction between the relation of job security and performance. The $\beta$ value positive shows positive relation where as 0.448 and $p=0.000$ considered as significant mediation found in the above stated hypothesis; hence, $\mathrm{H} 5$ is accepted.

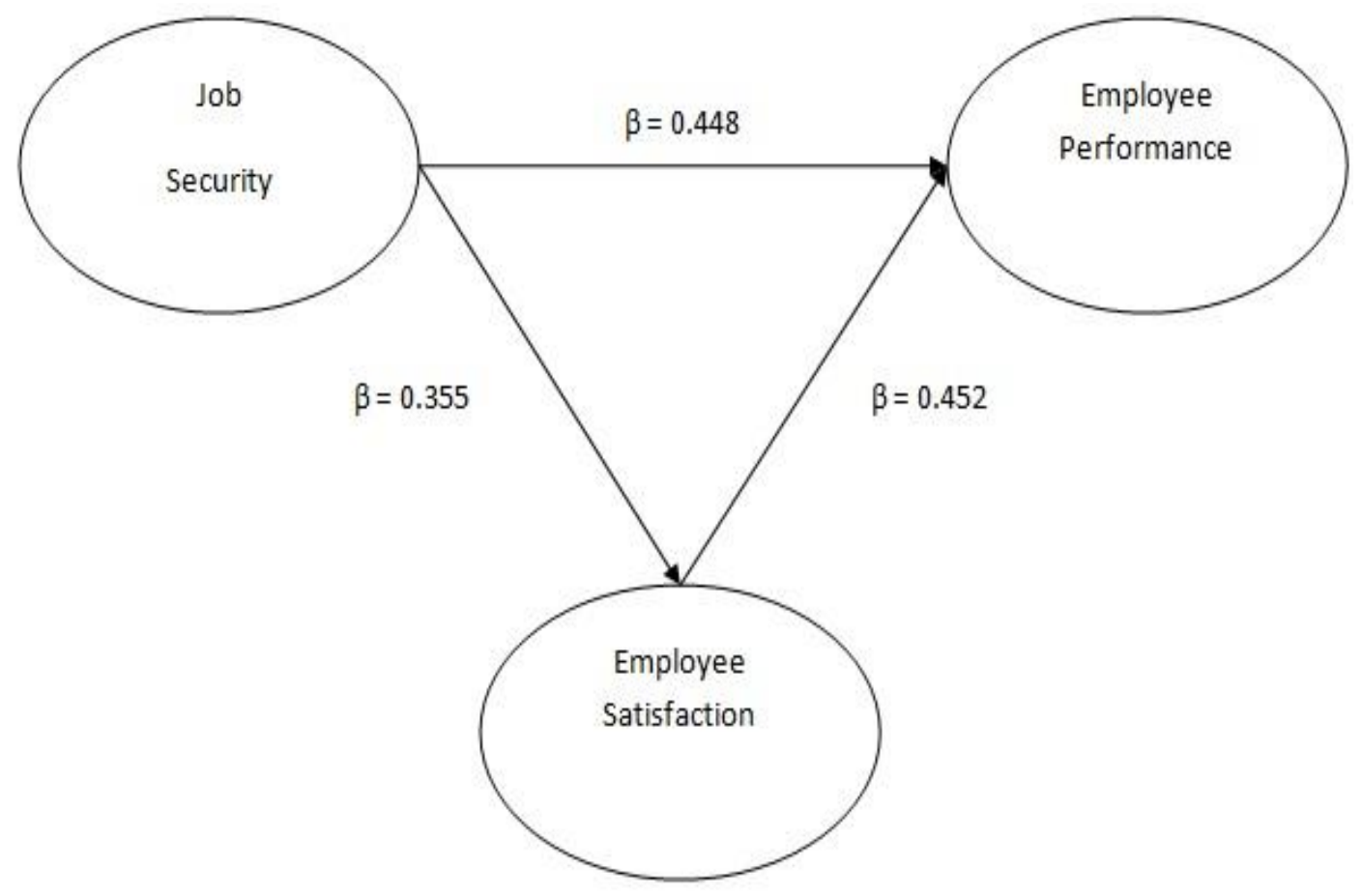

Fig 2; Mediation effect of employee satisfaction between job security and employee performance

H6: Employee Satisfaction mediate relationship between organizational support and performance Table 6 shows the results of $2^{\text {nd }}$ mediation effect of satisfaction between org-support and job performance. The statistics show that $\beta$ value found to positive and 0.289 whereas $p=0.000$; which shows positive significant mediation effect between these constructs; hence; $\mathrm{H} 6$ is accepted. 


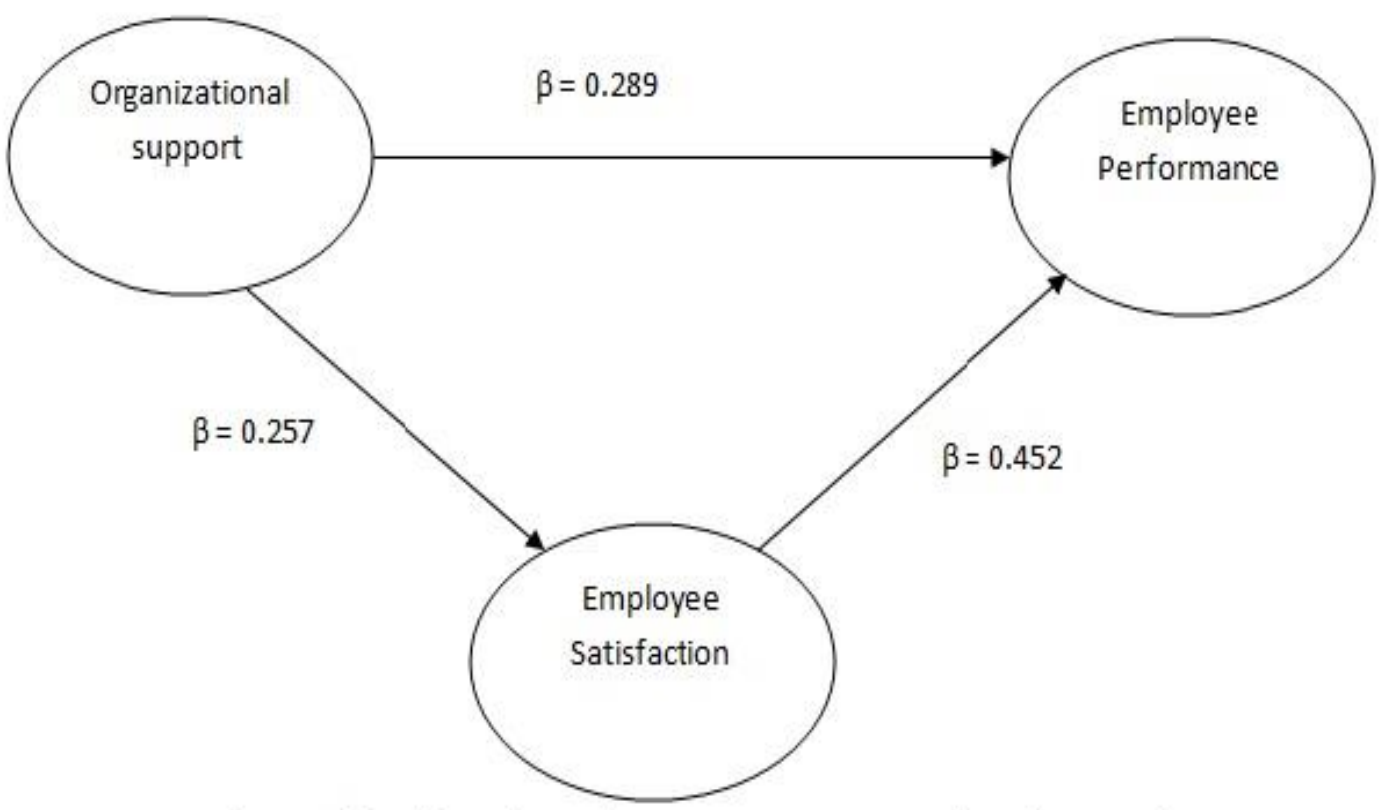

Fig: 3; Mediating effect of satisfaction between org support and employee performance

Table 6: Mediating effects:

\begin{tabular}{cccccc}
\hline IV & Effect of IV on & Direct effect of & Effect IV on & Direct effect & Indirect Effect \\
& Mediator & Mediator on & DV & Mediator on \\
& & DV & & DV \\
\hline Job security & $0.355^{* *}$ & $0.452^{* *}$ & $0.448^{* *}$ & $0.246^{* *}$ & $0.119 * *$ \\
Org-support & $0.257^{* *}$ & $0.452^{* *}$ & $0.289^{* *}$ & $0.183^{* *}$ & $0.104^{* *}$ \\
\hline
\end{tabular}

\section{Conclusion}

The study was conducted in Pakistani medical sector and public sector hospitals in province of Punjab; medical doctors in Pakistan initiated several strikes due to their un-satisfaction with policies related to job structure, job insecurity and lack of organizational support which ultimately destroy performance of employees. Due to these detrimental behavior and strikes of medical doctors generates negative consequences towards health of patients. The objective of the study entails to examine the relation between job security, organizational support and mediation effect of satisfaction towards prediction and measurement of performance of employees in medical sector of Punjab, Pakistan. Sample of 275 medical doctors were selected form province of Punjab from public sector hospitals, the study examined the relations of construct described earlier in subsequent part of study. The study found significant relations among constructs of the study, the study found significant positive relation between job security and employee satisfaction, which shows that if government and Pakistan Medical and Dental Council make sure proper and effective policies related to job structure for doctors, will be helping to gain satisfaction and further will be helping to improve 
performance of medical doctors. They study also found positive relation of organization support and satisfaction of employees at medical sector; if organization supports medical doctors for their job structure, security and payment policies will be influential towards better performance of employees. Further, mediating relationship was also found to be significant; study found significant positive relation and mediation effect of employee satisfaction between job security, organizational support and employee performance. The present study pinpoints the theory of social exchange theory whereas supportive management of organization and managers make sure job security of employees and in exchange process optimal performance is gained from the employee at workplace. Job security and organizational support influence the job performance with mediating effect of satisfaction of employees. The study contributed for managing human resource policies specially related to medical doctors in Pakistan public sector hospitals. The study provides the deep insight for government officials to emphasize specific issues of public sector medical doctors for improvement in their performance and outcomes for better health services to patients.

\section{References}

Ashford, S. J., Lee, C., \& Bobko, P. (1989). Content, cause, and consequences of job insecurity: A theory-based measure and substantive test. Academy of Management journal, 32(4), 803829.

Aziri, B. (2011). Job Satisfaction: A Literature Review. Management Research \& Practice, 3(4).

Balch, C. M., Freischlag, J. A., \& Shanafelt, T. D. (2009). Stress and burnout among surgeons: understanding and managing the syndrome and avoiding the adverse consequences. Archives of surgery, 144(4), 371-376.

Bernardin, H. J., \& Beatty, R. W. (1984). Performance appraisal: Assessing human behavior at work: Kent Publishing Company Boston.

Bourque, L., \& Fielder, E. P. (2003). How to conduct self-administered and mail surveys (Vol. 3): Sage. Bright, L. (2007). Does person-organization fit mediate the relationship between public service motivation and the job performance of public employees? Review of public personnel administration, 27(4), 361-379.

Brunetto, Y., \& Farr-Wharton, R. (2002). Using social identity theory to explain the job satisfaction of public sector employees. International journal of public sector management, 15(7), 534-551.

Buglear, J. (2005). Quantitative methods for business: The A-Z of QM. London:

Butterworth Heinemann.

Cheng, G. H. L., \& Chan, D. K. S. (2008). Who suffers more from job insecurity? A meta-analytic review. Applied Psychology, 57(2), 272-303.

Cheung, F. Y.-L., Wu, A. M., \& Chi, L. C. (2018). Effect of job insecurity, anxiety and personal resources on job satisfaction among casino employees in macau: A moderated mediation analysis. Journal of Hospitality Marketing \& Management, 1-18.

Cole, L., \& Cole, M. (2010). Employee satisfaction and organisational performance: A summary of key findings from applied psychology. Retrieved September 02, 2011.

Cuyper, D. N., \& De Witte, H. (2006). The impact of job insecurity and contract type on attitudes, wellbeing and behavioural reports: a psychological contract perspective. Journal of Occupational and Organizational Psychology, 79(3), 395-409. 
INTERNATIONAL JOURNAL OF ACADEMIC RESEARCH IN BUSINESS AND SOCIAL SCIENCES Vol. 9, No. 3, March, 2019, E-ISSN: 222 2-6990 @ 2019 HRMARS

Eisenberger, R., Fasolo, P., \& Davis-LaMastro, V. (1990). Perceived organizational support and employee diligence, commitment, and innovation. Journal of applied psychology, 75(1), 51.

Eisenberger, R., Huntington, R., Hutchison, S., \& Sowa, D. (1986). Perceived organizational support. Journal of Applied psychology, 71(3), 500.

Fischmann, G., De Witte, H., Sulea, C., \& Iliescu, D. (2018). Qualitative job insecurity and in-role performance: a bidirectional longitudinal relationship? European Journal of Work and Organizational Psychology, 27(5), 603-615.

Frone, M. R. (2018). What happened to the employed during the Great Recession? A US population study of net change in employee insecurity, health, and organizational commitment. Journal of Vocational Behavior, 107, 246-260.

Gabris, G. T., \& Simo, G. (1995). Public sector motivation as an independent variable affecting career decisions. Public Personnel Management, 24(1), 33-51.

Ghazali, S. S. A., Shah, I. A., Zaidi, S. A. A., \& Tahir, M. (2007). Job satisfaction among doctors working at teaching hospital of Bahawalpur, Pakistan. J Ayub Med Coll Abbottabad, 19(3), 81-83.

Glambek, M., Skogstad, A., \& Einarsen, S. (2018). Workplace bullying, the development of job insecurity and the role of laissez-faire leadership: A two-wave moderated mediation study. Work \& Stress, 1-16.

Greenhalgh, L., \& Sutton, R. (1991). Organizational effectiveness and job insecurity. Hartley, JF et al. Job insecurity: coping with jobs at risk. London, Sage.

Heaney, C. A., Israel, B. A., \& House, J. S. (1994). Chronic job insecurity among automobile workers: Effects on job satisfaction and health.

Hershcovis, M. S., Ogunfowora, B., Reich, T. C., \& Christie, A. M. (2017). Targeted workplace incivility: The roles of belongingness, embarrassment, and power. Journal of Organizational Behavior, 38(7), 1057-1075.

Hunter, S., Fears, S. K., Jones, D., \& Rennie, N. (2018). The Impact of Motivation on the Relationship of Academic Stress and Psychological Well-being Among College Students. Brenau University.

Jensen, J. M., Opland, R. A., \& Ryan, A. M. (2010). Psychological contracts and counterproductive work behaviors: Employee responses to transactional and relational breach. Journal of Business and Psychology, 25(4), 555-568.

Jermias, J., \& Yigit, F. (2012). Budgetary participation in Turkey: The effects of information asymmetry, goal commitment, and role ambiguity on job satisfaction and performance. Journal of International Accounting Research, 12(1), 29-54.

Judge, T. A., Thoresen, C. J., Bono, J. E., \& Patton, G. K. (2001). The job satisfaction-job performance relationship: A qualitative and quantitative review. Psychological bulletin, 127(3), 376.

Kazmi, A. (2011). Doctors strike-A result of rage or corruption. Retrieved on July, 9(201), 1.

Khan, A. H., Ahmad, I., Aleem, M., \& Hamed, W. (2011). Impact of job satisfaction on employee performance: An empirical study of autonomous medical institutions of Pakistan. International Journal of Management and Innovation, 3(2), 1.

Khan, M. (2015). The relationship between job performance, job security, organizational support, rewards and job satisfaction among medical doctors in Pakistan. Universiti Utara Malaysia.

Kneifel, S., Crewel, S., Redl, S., Steinke, S., Ohlwein, C., Keller, J., . . Pscheidt, I. (2012). Retrospective analysis of regional climate: The German reanalysis project-potential of remote sensing 
INTERNATIONAL JOURNAL OF ACADEMIC RESEARCH IN BUSINESS AND SOCIAL SCIENCES

Vol. 9, No. 3, March, 2019, E-ISSN: 222 2-6990 @ 2019 HRMARS

observations. Paper presented at the 2012 IEEE International Geoscience and Remote Sensing Symposium.

Kraimer, M. L., Wayne, S. J., Liden, R. C., \& Sparrowe, R. T. (2005). The role of job security in understanding the relationship between employees' perceptions of temporary workers and employees' performance. Journal of Applied Psychology, 90(2), 389.

Krejcie, R. V., \& Morgan, D. W. (1970). Determining sample size for research activities. Educational and psychological measurement, 30(3), 607-610.

Li, C., Liang, J., \& Farh, J.-L. (2018). Speaking Up When Water Is Murky: An Uncertainty-Based Model Linking Perceived Organizational Politics to Employee Voice. Journal of Management, 0149206318798025.

Lin, X. S., Chen, Z. X., Ashford, S. J., Lee, C., \& Qian, J. (2018). A self-consistency motivation analysis of employee reactions to job insecurity: The roles of organization-based self-esteem and proactive personality. Journal of Business Research, 92, 168-178.

Locke, E. A. (1976). The nature and causes of job satisfaction. Handbook of industrial and organizational psychology.

Luthans, F. (1998). Organisational Behavior, 8thedn: Irwin McGraw Hill, USA.

Madden, L., Kidder, D., Eddleston, K., Litzky, B., \& Kellermanns, F. (2017). A conservation of resources study of standard and contingent employees. Personnel Review, 46(3), 644-661.

Markovits, Y., Davis, A. J., Fay, D., \& Dick, R. v. (2010). The link between job satisfaction and organizational commitment: Differences between public and private sector employees. International Public Management Journal, 13(2), 177-196.

McGuigan, C. J., McGuigan, K., McGuigan, M., Shevlin, M., Mallett, J., \& Tracey, A. (2018). Modelling the role of personal factors as mediators in the relationship between workplace stress, motivation and job performance among Irish retail employees. International Journal of Business and Globalisation, 21(3), 426-450.

Miller, N. G., Erickson, A., \& Yust, B. L. (2001). Sense of place in the workplace: The relationship between personal objects and job satisfaction and motivation. Journal of Interior Design, 27(1), 35-44.

Millward, L. J., \& Brewerton, P. M. (2000). Psychological contracts: Employee relations for the twentyfirst century? International review of industrial and organizational psychology, 15, 1-62.

Morris, T., Lydka, H., \& O'Creevy, M. F. (1993). Can commitment be managed? A longitudinal analysis of employee commitment and human resource policies. Human Resource Management Journal, 3(3), 21-42.

Okpara, J. O. (2004). The impact of salary differential on managerial job satisfaction: A study of the gender gap and its implications for management education and practice in a developing economy. Journal of Business in Developing Nations, 8(1), 65-91.

Özyaman, F. B. (2007). Hemşirelerde iş güvencesi algısı ve anksiyete ve depresyon düzeylerine etkisi. DEÜ Sağlık Bilimleri Enstitüsü.

Posthuma, R. A., Charles Campion, M., \& Campion, M. A. (2018). A taxonomic foundation for evidence-based research on employee performance management. European Journal of Work and Organizational Psychology, 27(2), 168-187. 
INTERNATIONAL JOURNAL OF ACADEMIC RESEARCH IN BUSINESS AND SOCIAL SCIENCES Vol. 9, No. 3, March, 2019, E-ISSN: 222 2-6990 ¿ 2019 HRMARS

Probst, T. M., Stewart, S. M., Gruys, M. L., \& Tierney, B. W. (2007). Productivity, counterproductivity and creativity: The ups and downs of job insecurity. Journal of Occupational and Organizational Psychology, 80(3), 479-497.

Rehman, M. S. (2011). Exploring the impact of human resources management on organizational performance: A study of public sector organizations. Journal of Business Studies Quarterly, 2(4), 1.

Rhoades, L., \& Eisenberger, R. (2002). Perceived organizational support: a review of the literature. Journal of applied psychology, 87(4), 698.

Saari, L. M., \& Judge, T. A. (2004). Employee attitudes and job satisfaction. Human Resource Management: Published in Cooperation with the School of Business Administration, The University of Michigan and in alliance with the Society of Human Resources Management, 43(4), 395-407.

Şenol, F. (2011). The Effect of Job Security on the Perception of External Motivational Tools: A Study in Hotel Businesses. Journal Of Economic \& Social Studies (JECOSS), 1(2).

Shooshtarian, Z., Ameli, F., \& Amini Lari, M. (2013). The effect of labor's emotional intelligence on their job satisfaction, job performance and commitment. Iranian Journal of Management Studies, 6(1), 27-43.

Sirgy, M. J., Michalos, A. C., Ferriss, A. L., Easterlin, R. A., Patrick, D., \& Pavot, W. (2006). The qualityityof-life (QOL) research movement: Past, present, and future. Social indicators research, 76(3), 343-466.

Staufenbiel, T., \& König, C. J. (2010). A model for the effects of job insecurity on performance, turnover intention, and absenteeism. Journal of Occupational and Organizational Psychology, 83(1), 101-117.

Sultana, A. (2009). Level of Job Satisfaction in Doctors. Journal of Rawalpindi Medical College, 13(2), 95-97.

Sverke, M., \& Hellgren, J. (2002). The nature of job insecurity: Understanding employment uncertainty on the brink of a new millennium. Applied Psychology, 51(1), 23-42.

Talib, N., Khan, J., Kiran, A., \& Ali, R. (2017). Antecedents and Consequences of Job Satisfaction: Evidence from Hospitals of Khyber Pakhtunkhwa (KPK). Journal of Research in Social Sciences, $5(1), 83$.

Viswesvaran, C. (2001). Assessment of individual job performance: A review of the past century and a look ahead. Handbook of industrial, work and organizational psychology, 1, 110-126.

Xu, X.-D., Zhong, J. A., \& Wang, X.-Y. (2013). The impact of substitutes for leadership on job satisfaction and performance. Social Behavior and Personality: an international journal, 41(4), 675-685.

Zafar, J. (2015). The mediating effect of perceived employability on the relationship between protean career orientation, affective commitment and subjective career success among academics in Pakistan. Universiti Utara Malaysia. 